Digital Press Social Sciences and Humanities

Implementation of Early Childhood Education Policy in The Pandemic of COVID-19 In Indonesia

Serli Marlina and Nur Hazizah

Proceeding of The Non-Formal Education International Conference 2020

Alim Harun Pamungkas, Jamaris, Solfema (eds) 


\title{
Implementation of Early Childhood Education Policy in The Pandemic of COVID-19 In Indonesia
}

\author{
Serli Marlina*, and Nur Hazizah \\ Early Chilhood Education, Universitas Negeri Padang, Padang, Indonesia \\ *e-mail: serlimarlina@fip.unp.ac.id
}

\begin{abstract}
This study aims to describe the application of early childhood education policies in the middle of COVID19. This research method is a literature study, this study conducted a review of the literature-literature relating to the execution of early childhood instruction approach amid the COVID-19 pandemic in Indonesia. The results of this study found early childhood education policy during the COVID-19 pandemic was not implemented properly, the unequal internet access so parents cannot access learning and economic problems from parents so that they are unable to present tools for support online learning. the lack of parental knowledge of early childhood education. Learning at home must be in accordance with the interests and conditions of children not implemented because children tend to be left playing without supervision.
\end{abstract}

\section{Keywords}

COVID-19, Implementation, Education Policy, Early Childhood.

\section{Introduction}

The education system in Indonesia explains that Early Childhood Education, is a stimulation of development for newborn children up to the age of 6 ( $\mathrm{six}$ ) years carried out through the stimulation of all aspects of development with education aimed at helping the physical and inner growth and development of children so that children ready to face the next level of education (Hartoyo, 2004; Yuliani, 2009). Children at this age are the country's biggest assets in the next few years, because what we teach from an early age will be more easily absorbed and responded to by the child's brain. This educational process stimulates various aspects of children's development both in terms of devout and ethical values, cognitive, dialect, social-emotional, physical motor and arts. ECE is organized based on age groups and types of services, which include: ECE services for ages from birth to 6 (six) years consisting of "Child Care Parks and Similar Units" or ECE, and equivalent. ECE services for ages 2 (two) to 4 (four) years consisting of Play Groups. ECE services for ages 4 (four) to 6 (six) years consist of kindergartens / Raudhatul Athfal / Bustanul Athfal, and equivalent (Undang-undang, No. 20 Tahun 2003). This education is very meaningful for children, because there is age this is the foundation for children's readiness to face the next level of education and becomes a determinant for children's development at a later age. Experts call this age is the golden age. Therefore, parents and educators should not make mistakes in the process of stimulation because it will be stored directly in the brain of a child and is not easy to fix. Based on this, the policy of age education is very important in determining the quality of this golden generation.

Policy is a written rule that is a formal organizational decision, which is binding, regulating behavior with the aim of creating new values in society. Policy will be the main reference for members of the organization or community members in behavior (Dunn, 2003). Policies in general are problem solving and proactive. In contrast to Law and Regulation, policies are more adaptive and interpretative, although policies also regulate "what is permissible, and what is not permissible". Policies are also expected to be general but without eliminating specific local characteristics. "Policies must allow opportunities to be interpreted according to specific conditions. Education policy is public policy in the field of education (Tilaar \& Nugroho, 2009, p. 264)." The point here is that the policy made by the government is a policy that will be used by the public, especially in the field of education, therefore the policy set must look at the conditions and adjust to the real situation. Educational policy is a tool made by the government for the realization of a better change (Madjid, 2018, pp. 12-13). In this case, the official statement issued by 
COVID-19 task force and the Ministry of Education (2020) concerning the criteria for limiting travel of individuals during the pandemic (COVID-19) is an educational policy. This policy was born because of the spread of the corona virus in Indonesia so that the education process that was previously face to face turned into learning from home. The corona virus or COVID19 which was first discovered in Wuhan at the end of December 2019 is a new type of coronavirus that can be transmitted to humans very quickly and dangerously so that its spread has reached almost all corners of the world, even one of them is Indonesia with a population that is populated very much and dense.

The spread of COVID-19 virus has a negative impact on all levels of society, nations and countries, especially in the world of education. To prevent and stop the spread of the COVID-19 virus, the Indonesian government issued a Large-scale Social Restrictions (Pembatasan Sosial Berskala Besar) policy in almost every region in Indonesia. The impact is that schools are closed and the implementation of education that was previously face to face turned into an online system or online. Online learning that is designed for early childhood education is intended for parents to be able to guide and stimulate children at home. Learning that is carried out with the internet network is called online learning or online instruction. Online education connects students with subject matter via the internet (Johnson \& Manning, 2010, p. 10). Some call online education as cyber education or cyberspace classroom (Palloff \& Pratt, 2002, p. 20). Now there are those who use smart phones as a means of learning so-called m-learning or mobile learning (mobile learning) because teachers and students can move wherever they are (Allen \& Seaman, 2013, p. 7).

COVID-19 positive patient data on 21 April 2020, the total number of positive corona cases in Indonesia has now reached 7,135 patients, a sharp increase on 28 May 2020. as many as 24,538 patients (task force data) and on 6 June 2020 reaching 30,514 people spread across 34 Provinces of Indonesia (Idham, 2020). This data has increased from the previous month. The Ministry of Education and Culture has issued four policies during the COVID-19 pandemic, namely encouraging online learning both interactive and non-interactive, providing life skills education that is contextual and in accordance with children's conditions, learning at home must be in accordance with the interests and conditions of the child. for assignments and so on do not have to be assessed as usual. But it is qualitative and provides motivation for children. To implement the policy the Ministry of Education and Culture has prepared a platform for early childhood learning, the aim of which is to accommodate the implementation of online learning that will later be used by parents and teachers. The learning platform that has been prepared is Family Friend content, interactive online platforms, and social media, which can be an open source of learning for parents and teachers for early childhood learning at home, educational units and in the community. The Ministry of Education and Culture expects the learning platform to be a source of learning information and facilitate the implementation of student learning in the midst of corona virus outbreaks.

Problem formulation in this research is how is the implementation of education policies for children during the covid19 pandemic in Indonesia as well as the constraints in running education policies for children during the COVID-19 pandemic. This study aims to describe the implementation of the education policy of children during the 19th pandemic in Indonesia, and the constraints in implementing the education policy for children during the 19th pandemic.

This research is very useful for the government to conduct an ongoing policy evaluation and for early childhood education teachers and parents who have early childhood when carrying out early childhood education from home. Early Childhood Education is the foundation for children's education. This education is applied as the first step in the formation of the whole human character, namely the formation of personality, good character, smart, uplifting, skilled and devoted to God Almighty. This education starts from the environment closest to the child, the family, at the beginning of the child's development this education becomes the most priority because it will determine the child's success in the future. Therefore, the effort to stimulate children properly and in accordance with the principles of early childhood learning is learning while playing. Play is the most fun thing for children, by playing children to get the opportunity to find their true identity, express their feelings, create new things according to their imagination. The ECE Institute in Indonesia has a very strong foothold on the basis of its law, philosophical foundation, religious foundation, and scientific and empirical basis. Parents have a very important role in carrying out early childhood education. Because the process of enrolling children in school, completing the needs of school children and paying school fees and delivering and picking up children at school is the role and function of parents in the success of early childhood education. For this reason, it is very necessary for parents to understand this, so that the next generation of this nation will become quality seeds in building the future of their families, communities and countries. 
Arrangement could be a set of concepts and principles that direct and base the arrange within the usage of a work, authority, and way of acting. This term can be connected to governments, organizations and private segment bunches, as well as people. Approaches are distinctive from directions and laws. On the off chance that the law can force or forbid a behavior (for illustration a law that requires installment of salary assess), the approach is only a rule for activities that are most likely to get the required comes about.

Policy originates from an important decision-making process of an organization, including in identifying alternatives such as the basics and the policy also selects issues based on their impact. Policies can also mean mechanisms for achieving goals, about management, funding, or completeness to achieve specific objectives. Policy is a written rule that is a formal organizational decision, which is binding, which regulates behavior with the aim of creating new values in society. Policies are also expected to be general but without eliminating specific local characteristics and must allow opportunities to be interpreted according to specific conditions.

The policy making process is the basis for obtaining a policy. the policy making process is seen as a process of all parts related to the social system in the process of making system goals. External environmental factors, inputs, processes (transformation), output and feedback from the environment to policy makers are things that must be considered in the decision-making process. Related to this problem, policies are seen as: (1) guidelines for action, (2) behavioral barriers, and (3) assistance for decision makers (Imron, 1995; Pongtuluran, 1995, p. 7).

In the application of decentralization within the field of instruction, as a form of government policy implementation, School Based Management is implemented. With School-Based Management, schools that have been tightly controlled by the center have become more mobile, so quality can be improved. Empowering schools by giving greater autonomy is a responsive attitude of the government to the demands of society, as well as a means of increasing the efficiency of education. The responsibility of managing education is not only by the government but also by schools and the community in order to bring decision-making to the closest level to students. This School-Based Management at the same time strengthens democratic life through granting authority to the regions, resources and funds to the school level so that schools can become the main unit for improving the quality of independent learning (direct policy, budget, curriculum, teaching materials, and evaluation). "The School Based Management Program itself is a national program as stated in the Indonesian Education System: Administration of early childhood instructionunits, essential instruction and auxiliary instruction is carried out based on least benefit guidelines with the rule of school / madrasah-based administration ". In context, SchoolBased Management enables school organizations to be more responsive, adaptive, creative, in dealing with the demands of change due to external dynamics, and at the same time able to assess their internal strengths and weaknesses to continuously improve themselves.

The most point of School-Based Administration is to expanded proficiency, quality and value of instruction. Productivity changes are gotten through the flexibility to oversee existing assets, community interest and disentanglement of the bureaucracy. Quality change is gotten through parental support, adaptability in school administration, advancement of instructor polished skill, and other things that can cultivate a conducive atmosphere. Equitable instruction shows up within the development of community support (stakeholder), especially those who are able and concerned with education problems. The implication is giving greater authority to districts and cities to manage primary and secondary education in accordance with the potential and needs of the region. Also, make institutional changes to meet and improve efficiency and effectiveness in planning and implementation, as well as empowering human resources, which emphasizes professionalism.

The official government issue concerning criteria for limiting travel for persons in the context of handling Corona Virus Disease (COVID-19) (Kementerian Pendidikan dan Kebudayaan, 2020) is an educational policy. The Ministry of Education and Culture has issued four policies during the COVID-19 pandemic, namely encouraging online learning both interactive and non-interactive, providing life skills education that is contextual and in accordance with children's conditions, learning at home must be in accordance with the interests and conditions of the child. for assignments and so on do not have to be assessed as usual. But it is qualitative and provides motivation for children. 


\section{Methods}

The method used is literature review. Creswell (2015, p. 170) "explains the literature review could be a composed rundown of different diary articles, books, and other records that depict the circumstance of past and current data approximately the subjects examined." The meaning of a literature review is the process of gathering information about the topics discussed obtained from information that already existed from various writings or scientific works in the form of scientific articles, scientific magazines, books and other documents. The same thing was stated by Nazir (2003, p. 111) arguing that writing consider could be a information collection strategy by conducting a think about of books, writing, notes, and reports that are related to the issue being fathomed. Researchers conduct studies relating to theories related to research topics, gathering as much information as possible from related literature. This research conducted a study of literature review related to the implementation of early childhood education policies during the pandemic in Indonesia. Data was collected from online journals and online news when the early childhood education policy took effect during the pandemic period in Indonesia.

\section{Results and Discussion}

Educational policy has three main elements, namely problems, goals, and ways of solving problems (Madjid, 2018, pp. 16-21). Two of the objectives of public policy are regulative or deregulative and dynamic or stabilization (Nugroho, 2017, p. 171). Good policies are made scientifically, openly, fairly, aiming at problem solving, and formulated with clear sentences (Sugiyono, 2017, p. 6). The results of a literature study from online journals and online news about the usage of the early childhood instruction approach of Covid -19

\subsection{Online Learning Both Interactive and Non-Interactive}

To implement this policy the government has prepared a platform for early childhood learning, the goal is to accommodate the implementation of online learning that will later be used by parents and teachers. The learning platform that has been prepared is Family Friend content, an interactive online platform, and social media, which can be an open source of learning for parents and teachers for early childhood learning at home, educational units and in the community. Provide contextual life skills education and according to the child's condition.

This modern learning model is regulated in the statement issued by the Ministry of Education Number 22 (2016) concerning standard procedure of primary and secondary education with the following principles: initially the students are always told to learners looking for their own information, starting from the teacher as the only source of learning information to learn based on various learning sources, before textual approach to the process as a result of information elaboration, before knowledge-based learning towards learning to process various things what is known, begins learning specializing material towards integrated learning, previously learning that emphasizes the results of answers or values switched with answers whose truth is based on a variety of skills, the learning process relies only on verbal skills replaced with the skills of applying what is already known, stimulating and balancing physical aptitudes (hard skills ) and mental abilities (soft skills), learning that prioritizes the culture and empowerment of children to become lifelong learners, learning that applies values by exemplary (ing ngarso sung tulodo), building the will (ing madyoo mangun karso), and developing all the creativity of children in the learning process (tut wury handayani), previously learning must be at school now learning can also be optimized in each home, and in the community, learning that promoting the principle of learning can be from nature and the people around them and they can be a source of learning, and being anywhere can be a learning space, utilizing existing information and communication technology to improve the efficiency and effectiveness of leaarning and respecting the differences of each child and the child's cultural background (Charismiadji, 2020)." In the fabric of human life there is always change, especially in the acquisition of knowledge. Along with the development of technology, the learning process must also continue to develop. Every human being can be a teacher or a source of learning for others. Studying can be done anywhere, starting from home, the community and school. The use of 
information technology is clearly seen in the current pandemic. For the sake of the continuation of the learning process, various methods are carried out by the government with the aim of the community to still get information and education that is appropriate for students who are educating.

The online learning implementation of the Cikal Main House teachers every day first had a discussion on the development of interesting learning content together with the academic team and the Cikal Main House teachers. The discussion includes forming a learning unit, determining learning objectives so that a series of activities will be carried out by children at home with their parents (Prodjo, 2020b).

Some aspects that need to be considered in the implementation of e-learning are planning, measuring student needs, support systems, teacher competencies, material design, appropriate platforms, and evaluating student learning outcomes (Lynch, 2002, pp. 3-4). Other experts are of the opinion that aspects that are considered in e-learning are students, teachers, learning materials, technology or platforms used, and learning environments (Finger, 2007, p. 67). Platforms in e-learning systems, namely learning management systems (LMS) are forming virtual learning environments (Coates, 2006, p. 43). Three main aspects of e-learning are developers, educators, and students. E-learning will succeed if it pays attention to access and technology, guidelines and procedures, maximum student participation, collaborative learning implemented by the teacher, and the presence of interaction (Palloff \& Pratt, 2002, p. 26). From some of the opinions above, the policy and implementation of e-learning should pay attention to aspects of students, teachers, supporting facilities, material, evaluation, interaction, technology platforms used, and learning management systems. Some research results related to the application of e-learning with various terms used in PAUD show the results and positive impact on students.

So far, no PAUD teacher has ever received e-learning training from the Education and Culture Office or from the Ministry of Religion. The condition of the COVID-19 pandemic forced teachers to implement elearning because there was no other choice after the issuance of a policy of gathering people and maintaining physical distance. Based on a questionnaire related to the experiences of PAUD teachers in implementing e-learning as much as $81 \%$ of teachers have never applied e-learning, which sometimes applies $13 \%$ and who often apply as much as $6 \%$. Chances are those who have already applied e-learning due to their experiences while studying or studying independently. The respondent's acknowledgment is in accordance with MoRA data that only $1 \%$ of students have used e-learning and as many as $22 \%$ of teachers in the Ministry of Religion have used e-learning, and 14\% of madrasah institutions have used elearning. The data breakdown is the total number of madrasas 82,418 but 11,289 e-learning institutions. The total number of madrasah teachers is 268,706 while the number of e-learning teachers is 59,615 . Seen from the total number of madrasah students $9.45,198$ people while the number of e-learning students is 60,401 people.

On the other hand, online learning at home also presents problems for parents, learning at home is also considered to have more expenditure on credit and internet quota to support the learning process, but many parents feel learning at school and at home both have a lot of expenditures when viewed from outgoing pocket money or other factors that make learning at school and at home have different expenditures but are equally assessed expenditures made are considered to be reasonable. This is consistent with the constraints faced by parents are the increase in the cost of purchasing internet quota increases, online technology requires a network connection to the internet and quota therefore the level of internet quota usage will increase and will increase the burden on parents spending, to do online learning during a few months will certainly require more quota and will automatically increase the cost of purchasing internet quota. Another obstacle in the implementation of this policy is the absence of internet services, so that children in disadvantaged areas have not studied for the past 3 months. The students now only help their parents in their fields because there is no internet service. These disadvantaged areas also have no electricity so they cannot access education at all online.

\subsection{Provide Life Skills Education that is Contextual and in Accordance with the Child's Condition}

All stimulation in learning process to achieve all 6 aspects of child development so that children can solve their problems daily through life skills education is still lacking. "Learning life skills education in accordance with the stages of early childhood development effectively (Slamet, 2002). Life skills education is grouped into four types, namely: a) personal skills, b) social skills, c) academic skills and d) vocational skills." The aspect of the problems faced by the Pos ECE partner in Ngijo Urban Village is that 
the tutor has difficulty in teaching life skills in a concrete and practical manner regarding problems that are often faced by children in daily life. Tutor has difficulty managing learning that guides children to have holistic, concrete and functionally meaningful child development competencies for solving everyday problems. The perception of tutors to teach early childhood is important is that children love to play.

Based on this, skills from parents and teachers are needed to stimulate child development. Parents and teachers must also provide assistance in play, because the process of stimulation of children's development is integrated in play. Play is a necessity for children. When playing children will explore all the potential that exists in him for that when playing children need friends, play equipment outdoors and indoors, a large area, a safe and comfortable place and can protect children from all kinds of diseases, including avoiding virus transmission. But it is unfortunate, at this time children are no longer easy to do that, because of the Corona virus (COVID-19) that threatens children's health.

\subsection{The learning process that is done from home must be done according to the interests and conditions of the child}

Interest is a feeling that is shown by children in their play activities. Anat interest in something will be seen when children play toys repeatedly. Interest should be a special concern for parents, because by knowing the interests of children, parents can enter the stimulation process in the game that is of interest to the child. The child's condition is the time when the child has to play, rest and do other activities. Parents must understand this, because now is the right time the child can be invited to play and be stimulated so that the process of playing activities becomes meaningful. Children learn according to their interests so that learning at home is carried out according to the interests and conditions that are right for children (Slameto, 2010).

The reality now is that learning at home is not easy for parents. Especially for parents busy working outside the home. They have to go to work from the morning when their child is still sleeping and come home at night when the child is asleep. Some parents who are not busy they are constrained by inviting children to learn and accompany children when learning, so that children play without supervision. Parents who are busy working at home, they are more inclined to give Android so that their children play games and not interfere with their work, but unfortunately without supervision.

\subsection{Tasks And so on do Not Have to be Assessed as Usual But it is Qualitative and Provides Motivation for Children}

Some schools implement this policy by giving assignments then asking children to do it, both in the form of recordings and photographs. So many parents are inconvenienced due to the many assignments given by the school. There is a misinterpretation of students' parents and even teachers about learning at home during the corona pandemic (Souisa, Salim, \& Renaldi, 2020). The school was impressed only moved the learning process from class to home. Materials and assignments are provided online or online, through various platforms provided by the government and the private sector (Prodjo, 2020a). In contrast to the policies circulated, Plt. The Director of Teacher Development and Education Personnel for Early Childhood Education (PAUD) Kemendikbud stated, the time of study at home for PAUD students is when they play and spend time with their parents. PAUD teachers must improve communication with students' parents during the study period at home. He asserted, for PAUD, there is no such thing as an assignment from a teacher to children. With this instruction the dominant age education teacher does not give assignments to children at home. For this reason, this policy is not implemented as it should be due to the different views between policy makers and

\section{Conclusions}

Referring to the results of the above thoughts and opinions that the policy towards early childhood education during the co-19 pandemic cannot be implemented properly due to many obstacles from various aspects. The constraint of implementing online learning policies both interactive and noninteractive is the uneven internet access so parents cannot access learning and economic problems from 
parents so they are unable to present tools to support online learning. The obstacle of implementing policies to provide life skills education that is contextual and appropriate to the child's condition is the lack of parental knowledge of early childhood education so that managing learning that guides children has holistic, concrete and functionally meaningful child development competencies for solving everyday problems. The perception of tutors to teach early childhood is important is that children love to play. Learning at home must be in accordance with the interests and conditions of children not implemented because children tend to be left playing without supervision. Tasks and so on do not have to be assessed as usual. But it is qualitative and provides motivation for children. Not implemented properly because there are differences between the policies issued by the government and the policies of the Director of Teacher Development and Early Childhood Education Personnel.

\section{References}

Allen, E. I., \& Seaman, J. (2013). Changing Course: Ten Years of Tracking Online Education in the United States. In Sloan Consortium. Newburyport.

Charismiadji, I. (2020). Mengelola Pembelajaran Daring yang Efektif. Retrieved from Detik News website: https://news.detik.com/kolom/d-4960969/mengelola-pembelajaran-daring-yang-efektif

Coates, H. (2006). Student Engagement in Campus-Based and Online Education: University Connections. New York: Routledge.

Creswell, J. W. (2015). Educational Research: Planning, Conducting, and Evaluating Quantitative and Qualitative Research (5th ed.). Boston: Pearson Education.

Dunn, W. N. (2003). Pengantar Analisis Kebijakan Publik (2nd ed.; M. Darwin, Ed.; S. Wibawa, D. Asitadani, A. H. Hadna, \& E. A. Purwanto, Trans.). Yogyakarta: Gadjah Mada University Press.

Finger, G. (2007). Online Learning and Lifelong Learning: Implications for Transforming Teachers and Learning. In Y. Inoue (Ed.), Online Education for Lifelong Learning. Hershey: Information Science Publishing.

Hartoyo, B. (2004). Konsep Dasar Pendidikan Anak Usia Dini, Materi Tutor dan Pengelola Pendidikan Anak Usia Dini. Semarang: BPPLSP Regional III Jawa Tengah.

Idham, A. M. (2020). Update Corona Indonesia 21 April 2020 \& Data Covid-19 Dunia Terkini. Retrieved from Tirto.id website: https://tirto.id/update-corona-indonesia-21-april-2020-data-covid-19dunia-terkini-ePYZ

Imron, A. (1995). Kebijakan Pendidikan Indonesia. Jakarta: Bumi Aksara Daerah.

Johnson, K., \& Manning, S. (2010). Online Education for Dummies. Ottawa: John Wiley \& Sons.

Kementerian Pendidikan dan Kebudayaan. Standar Proses Pendidikan Dasar dan Menengah. No 22, (2016). Indonesia.

Kementerian Pendidikan dan Kebudayaan. Surat Edaran Tentang Pencegahan COVID-19 pada Satuan Pendidikan. No 3 , (2020). Indonesia.

Lynch, M. M. (2002). The Online Educator: A Guide to Creating the Virtual Classroom. New York: Routledge.

Madjid, A. (2018). Analisis Kebijakan Pendidikan. Yogyakarta: Samudera Biru.

Nazir, M. (2003). Metode Penelitian. Jakarta: Ghalia Indonesia.

Nugroho, R. (2017). Public Policy (6th ed.). Jakarta: Elex Media Komputindo.

Palloff, R. M., \& Pratt, K. (2002). Lessons from the Cyberspace Classroom: The Realities of Online Teaching. San Francisco: Jossey-Bass.

Pongtuluran, A. (1995). Kebijakan Organisasi dan Pengambilan Keputusan Manajerial. Jakarta: LPMP.

Prodjo, W. A. (2020a). Apa itu Belajar dari Rumah? Melihat Kembali Konsep Awal. Retrieved from Kompas website: https://edukasi.kompas.com/read/2020/04/14/163041771/apa-itu-belajar-dari-rumahmelihat-kembali-konsep-awal?page=all

Prodjo, W. A. (2020b). Belajar dari Rumah: Begini Cara Belajar Siswa PAUD Rumah Main Cikal. Retrieved 
from Kompas website: https://www.kompas.com/edu/read/2020/04/01/145223271/belajardari-rumah-begini-cara-belajar-siswa-paud-rumah-main-cikal?page=all

Slamet, P. H. (2002). Pendidikan Kecakapan Hidup: Konsep Dasar. Jurnal Pendidikan Dan Kebudayaan, 8(37), 23-37.

Slameto. (2010). Belajar dan Faktor-faktor yang Mempengaruhi. Jakarta: Rineka Cipta.

Souisa, H., Salim, N., \& Renaldi, E. (2020). Pengalaman Belajar dari Rumah di Tengah Pandemi Virus Corona Menunjukkan Masih Adanya Kesenjangan Pendidikan di Indonesia. Retrieved from ABC News Indonesia website: https://www.abc.net.au/indonesian/2020-05-28/masalah-belajar-darirumah-di-tengah-pandemi-virus-corona/12291408

Sugiyono. (2017). Metode Penelitian Kuantitatif, Kualitatif, dan R\&D. Bandung: CV Alfabeta.

Tilaar, H. A. R., \& Nugroho, R. (2009). Kebijakan Pendidikan: Pengantar Untuk Memahami Kebijakan Pendidikan Dan Kebijakan Pendidikan Sebagai Kebijakan Publik. Yogyakarta: Pustaka Pelajar.

Yuliani, N. S. (2009). Konsep Dasar Pendidikan Anak Usia Dini. Jakarta: PT Indeks. 